Oikos 000: 001-012, 2014

doi: $10.1111 / j .1600-0706.2013 .00860 . x$

(C) 2014 The Authors. Oikos (C) 2014 Nordic Society Oikos

Subject Editor: Timothy Cavagnaro. Accepted 24 November 2013

\title{
Nitrogen limitation and microbial diversity at the treeline
}

\author{
Aurélie Thébault, Jean-Christophe Clément, Sébastien Ibanez, Julien Roy, Roberto A. Geremia, \\ Cecilia A. Pérez, Alexandre Buttler, Yvan Estienne and Sandra Lavorel
}

A. Thébault and A. Buttler, Ecole Polytechnique Fédérale de Lausanne (EPFL), School of Architecture, Civil and Environmental engineering (ENAC), Laboratory of Ecological Systems, Station 2, CH-1015 Lausanne, Switzerland, and WSL Swiss Federal Res. Inst., Site Lausanne, Station 2, CH-1015 Lausanne, Switzerland. - J.-C. Clément (jean-christophe.clement@ujf-grenoble.fr), S. Ibanez, J. Roy and R. A. Geremia, Laboratoire d'Ecologie Alpine, CNRS UMR 5553, Univ. Joseph Fourier, BP 53, FR-38041 Grenoble Cedex 9, France. - S. Lavorel and SI, WSL Swiss Federal Res. Inst., Site Bellinzona, Station 2, CH-6500 Bellinzona, Switzerland. Present address for SL: Laboratoire d'Ecologie Alpine, UMR CNRS 5553, Université de Savoie, 73376 Le Bourget-du-lac, France. - C. A. Pérez, Pontificia Univ. Católica de Chile, Center for Advanced Studies in Ecology and Biodiversity, Depto de Ecología, Alameda 340, Santiago, Chile. - Y. Estienne, Azimut, route des Ecrins, FR-05120 Les Vigneaux, France.

\begin{abstract}
Tree growth limitation at treeline has mainly been studied in terms of carbon limitation while effects and mechanisms of potential nitrogen $(\mathrm{N})$ limitation are barely known, especially in the southern hemisphere. We investigated how soil abiotic properties and microbial community structure and composition change from lower to upper sites within three vegetation belts (Nothofagus betuloides and $N$. pumilio forests, and alpine vegetation) across an elevation gradient (from 0 to $650 \mathrm{~m}$ a.s.l.) in Cordillera Darwin, southern Patagonia. Increasing elevation was associated with a decrease in soil $\mathrm{N}_{-} \mathrm{NH}_{4}{ }^{+}$availability within the $N$. pumilio and the alpine vegetation belt. Within the alpine vegetation belt, a concurrent increase in the soil C:N ratio was associated with a shift from bacterial-dominated in lower alpine sites to fungal-dominated microbial communities in upper alpine sites. Lower forested belts (N. betuloides, N. pumilio) exhibited more complex patterns both in terms of soil properties and microbial communities. Overall, our results concur with recent findings from high-latitude and altitude ecosystems showing decreased nutrient availability with elevation, leading to fungal-dominated microbial communities. We suggest that growth limitation at treeline may result, in addition to proximal climatic parameters, from a competition between trees and soil microbial communities for limited soil inorganic N. At higher elevation, soil microbial communities could have comparably greater capacities to uptake soil $\mathrm{N}$ than trees, and the shift towards a fungal-dominated community would favour $\mathrm{N}$ immobilization over $\mathrm{N}$ mineralization. Though evidences of altered nutrient dynamics in tree and alpine plant tissue with increasing altitude remain needed, we contend that the measured residual low amount of inorganic $\mathrm{N}$ available for trees in the soil could participate to the establishment limitation. Finally, our results suggest that responses of soil microbial communities to elevation could be influenced by functional properties of forest communities for instance through variations in litter quality.
\end{abstract}

Treelines, defined here as the upper limits of altitudinal tree distribution referring to upright trees taller than $3 \mathrm{~m}$ (krummholz), are among the most obvious climate-driven ecological boundaries. At global scale, the narrow range of mean air temperature at treeline $\left(6.7 \pm 0.8^{\circ} \mathrm{C}\right.$ growing season temperature) supports the hypothesis of a common global thermal threshold for forest growth at high altitude/ latitude (Körner and Paulsen 2004), but the causes of treeline formation are not fully resolved. Given observed responses of latitudinal and altitudinal treelines to the increase of global temperature during the last century (Payette 2007) and the fact that organisms close to their physiological limit may be particularly susceptible to climate change (Wookey et al. 2009), an improved understanding of the environmental constraints on tree recruitment and growth at these locations is a priority for predicting future treeline shifts.
At high altitude, low temperatures impact tree physiology leading to growth-limitation (Körner and Paulsen 2004). From a global perspective, the most plausible explanations for treeline formation are the sink and source limitation hypotheses (Körner 1998). The sink (or growth) limitation hypothesis, states that despite an abundant resource supply allowing photosynthesis, low temperatures limit the rate at which carbon can be used for structural growth (Shi et al. 2008). The source hypothesis is based on the assumption that tree growth is limited by insufficient carbon assimilation by photosynthesis, which is most likely to arise from low nutrient availability, drought stress, or loss or damages of tissues responsible for carbon or nutrient acquisition and assimilation (Susiluoto et al. 2010). In the context of the source limitation hypothesis however, the role of nutrient limitation has received less 
attention than the carbon-limitation hypothesis despite the fact that $\mathrm{N}$ and $\mathrm{C}$ are closely linked through net primary production and soil organic matter mineralization. At higher latitudes or elevations, cold climate, the short growing season and the poor quality of plant material combine to limit soil microbial activities, rates of litter decomposition, and soil organic matter (SOM) turnover (Loomis et al. 2006), though wintertime litter decomposition has been shown to occur depending on the snowpack characteristics (Saccone et al. 2013). Soil organic matter tends to accumulate with elevation up to the montane forest belt, and then decreases above the tree line, reaching almost zero in un-vegetated substrates of the upper alpine zone (Körner 1998). Since large amounts of $\mathrm{N}$ are stored in SOM, its availability, either in its organic or inorganic forms, is therefore reduced with elevation (Loomis et al. 2006).

To date, most studies have focused on documenting such patterns of limited nutrient availability and associated processes, but the need for fundamental understanding of underlying soil biotic processes has become increasingly apparent (Wookey et al. 2009, Sundqvist et al. 2011, McNown and Sullivan 2013). Above- and below-ground communities are indeed intimately linked. On one hand, soil microbiota plays a prominent role in tree nutrition and growth through its implication in SOM recycling. On the other hand, plant organic matter quality contributes to selecting specific microbial functional groups and traits, and thereby feeds back to $\mathrm{C}$ and $\mathrm{N}$ cycling (Wardle et al. 2004). Revealing how such dynamics might contribute to nutrient limitation at treelines appears therefore as a promising avenue to understand $\mathrm{N}$-related treeline mechanisms (McNown and Sullivan 2013). It has been observed that microbial activities, enzymatic reactions and abundances of psychrophilic fungi vary significantly with altitude with some cold-tolerant fungi remaining physiologically active down to $-10^{\circ} \mathrm{C}$ (Loomis et al. 2006). At the same time, changes in the physiology and productivity of dominant trees result in altered nutritional quality (e.g. decreasing $\mathrm{N}$ content) of plant material with increasing altitude (van de Weg et al. 2009). More specifically, in a recent study Sundqvist et al. (2011) confirmed the applicability to treelines of the positive feedback loop linking $\mathrm{N}$ availability, bacteria:fungi prevalence, and plant and soil nutrient cycling (Wookey et al. 2009). An increased dominance of fungi over bacteria, associated with lower soil $\mathrm{N}$ availability, poorer quality of plant material and indices of slower $\mathrm{C}$ and $\mathrm{N}$ cycling, were observed with increasing altitude and decreasing temperature. But, while recent studies have highlighted functional shifts within microbial communities associated with $\mathrm{N}$ limitation at the treeline (Sundqvist et al. 2012), little is known about associated changes in microbial community composition for bacteria and fungi, and their direct relationships to $\mathrm{N}$ availability in terms of quantity (available labile $\mathrm{N}$ ) and quality (e.g. soil C:N ratio). Previous studies in alpine tundra have highlighted profound changes in microbial community composition in response to heterogeneity in snow cover (i.e. snowbeds vs wind-swept ridges), and their consequences for carbon cycling (Baptist et al. 2010, Zinger et al. 2011). However, such detailed knowledge of spatial turnover in microbial communities is not available for treelines.
One further related mechanism, which to our knowledge has not been investigated in the context of treelines (in contrast to alpine tundras), concerns the partitioning of soil $\mathrm{N}$ resources between plants, including trees, and soil microbial communities (van der Heijden et al. 2008). Briefly, under conditions where $\mathrm{N}$ is limited, and in particular in cold pristine ecosystems, plants and soil microbes compete for limited $\mathrm{N}$ supply so that, depending on plant strategies, local conditions, and season, labile inorganic $\mathrm{N}$ may be taken up either by plant or microbial growth (Harrison et al. 2008). Under limited soil $N$ availability, such competition may be acute at treelines, and contributes, along with altered microbial functional composition and activities, to further restricting $\mathrm{N}$ access to trees and hence their growth.

Most of the above-cited studies investigating treeline physiological and soil-related mechanisms have been conducted in the northern hemisphere. In addition to missing detailed mechanistic insights as highlighted above, it is also not known whether current knowledge applies to the southern hemisphere. Treelines of the southern hemisphere are at least $200 \mathrm{~m}$ lower than expected from the treelinetemperature relationship observed in the northern hemisphere (Körner and Paulsen 2004), and have original structures. In the northern hemisphere, treelines, mostly composed of coniferous species, follow a gradual transition from closed canopy forest to small clumps of trees and lastly to scattered individuals until the tree limit is reached. By contrast, in the southern hemisphere, treelines, dominated by light-demanding species such as Nothofagus sp., form sharp boundaries (Körner and Paulsen 2004). At the upper limit, Nothofagus treelines are characterised by a krummholz growth form, i.e. above-ground morphological adaptation to harsh conditions, which has been suggested to reflect below-ground adaptation to faster nutrient cycling (Frangi et al. 2005). Northern and southern hemisphere treelines have also shown different responses to temperature increase. Over the last decade trees have established rapidly beyond the treeline in the northern hemisphere (e.g. larch treelines shifted $115 \mathrm{~m}$ upward between 1901 and 2000 in the western Italian Alps, Leonelli et al. 2011), but not in the southern hemisphere (reviewed by Cullen et al. 2001). For instance, in New Zealand, treeline upward shift was less than $10 \mathrm{~m}$ despite the temperature increase of $1^{\circ} \mathrm{C}$ since 1950 (Wardle and Coleman 1992). In Chile, seedlings have been found until $20 \mathrm{~m}$ beyond the current treeline but with a low survival rate, suggesting that the establishment of a new treeline beyond $10 \mathrm{~m}$ is unlikely (Cuevas 2000). Overall, these differences between northern and southern hemisphere treelines suggest that other drivers than climate alone may be at play.

In southern Patagonia, the upper range of Cordillera Darwin has never been impacted by humans and total atmospheric $\mathrm{N}$ deposition ranges from 1 and $5 \mathrm{~kg} \mathrm{~N} \mathrm{ha}^{-1}$ year $^{-1}$, which is extremely limited compared to Europe or northeastern Unites States (Reay et al. 2008). In such a context, the current treeline is assumed to be strictly driven by natural factors, and represents a prime model to discover key mechanisms limiting altitudinal expansion of trees. To explore potentially novel mechanisms in tree growth limitation we investigated, along an elevational gradient, the relationships between the availability of different soil $\mathrm{N}$ 
forms, the vegetation type, and the soil microbiota composition. We hypothesized that within a given vegetation belt, upper sites experienced more stressful conditions than lower sites in terms of $\mathrm{N}$ availability, resulting in changed microbial communities, greater competition between trees and microbes, and ultimately slower N cycling. Specifically, we expected increasing elevation to be paralleled by a reduction in soil inorganic $\mathrm{N}$ content and an increase in soil C: $\mathrm{N}$ ratio, while fungal communities would become dominant, and microbial community composition would change drastically.

\section{Material and methods}

\section{Field location}

Sampling was carried out at the end of October 2009 (mid austral spring) in Cordillera Darwin, at the southwest of the main island (Isla Grande) of Tierra del Fuego (Chile). Cordillera Darwin is the most southern mountain range of the Andes that is covered with glaciers, with Mount Darwin culminating at $2488 \mathrm{~m}$ a.s.l. (Fig. 1). The Beagle Channel is the southern limit of Cordillera Darwin, with several fjords entering deep inside the mountains. All samples were collected in Bahia Pia, a fjord located at the south of Mount Darwin $\left(54^{\circ} 44^{\prime} 30^{\prime \prime} \mathrm{S}, 69^{\circ} 30^{\prime} 10^{\prime \prime} \mathrm{W}\right)$. The forest in this area is free of any human activities and difficult to access because of its remoteness and the extreme weather conditions in the mountains and on the sea. To access and stay in Bahia Pia, we therefore collaborated with the French mountaineering expedition 'Un rêve de Darwin' (<www.unrevededarwin.com>).

\section{Vegetation belts}

Schematically, three vegetation belts can be distinguished in Bahia Pia, as in southern Patagonia and Tierra del Fuego in general (Aravena et al. 2002). The vegetation is dominated by the evergreen Nothofagus betuloides ('coihue de Magallanes' in chilean spanish) from sea-level to 200-300 m a.s.l. Coihue forms forests of $20-40 \mathrm{~m}$ high and the understory is mainly composed by mosses, Gaultheria mucronata and Berberis ilicifolia ('calafate'). Above 250-300 m a.s.l., coihue forest is replaced by the deciduous Nothofagus pumilio ('lenga') with smaller trees (10-20 m high) and a soil almost exclusively covered by mosses and some Gaultheria mucronata. The continuous lenga forest ends at $450-500 \mathrm{~m}$ a.s.l. and is replaced by an alpine belt. The alpine belt is more heterogeneous with respect to vegetation. Indeed, the most abundant vascular species is Empetrum rubrum (murtilla de Magallanes), followed by dwarf
Nothofagus pumilio (krummholz growth form) and graminoid species that could not be determined since sampling was done in early spring, when the alpine communities, as well as most of the other sites, were still snow covered. Consequently, due to the seasonal timing of the sampling, plant community composition, plant cover and aboveground biomass could not be documented.

The bedrock in Bahia Pia is made of unfractured and monolithic granit, except in moraine areas. As a consequence, the soil is not mixed with macroscopic mineral fragments and there is a sharp limit between topsoil and underlying bedrock. Within each vegetation belt, the depth of the soil varies between a few to $60 \mathrm{~cm}$.

\section{Sampling protocol}

In late October 2009, 24 sites situated along four altitudinal transects were sampled in Bahia Pia for soil and microbial analyses. A transect was composed of six sampling sites distributed along the altitudinal gradient (Table 1), covering the three vegetation belts ( $N$. betuloides, $N$. pumilio and alpine vegetation). Two different sites were sampled within each vegetation belt: one site at lower altitude, relative to its position on the altitudinal gradient (bet1, pum1, alp1), and one site at higher altitude (bet2, pum2, alp2; Fig. 1). Listed in order of ascending altitude, these were: 1) and 2) two sites in the Nothofagus betuloides forest (bet1 and bet 2 respectively), 3) a site at the upper limit of the Nothofagus pumilio forest (pum1), 4) 10-100 m apart the former site, a site at the lower limit of the alpine environment (alp1), 5) a site in the dwarf Nothofagus pumilio (i.e. Krummholz form) that are in the upper part of the alpine belt (pum2), 6) 10-100 m apart from the former site, a site in the alpine communities (alp2). For each site, we sampled five soil cores ( $10 \mathrm{~cm}$ diameter) in a $5 \mathrm{~m}$ radius plot. Soil cores depth encompassed all the available soil profile and ranged from 2 to $60 \mathrm{~cm}$ depending on the site (Table 1). In total, we collected four transects $X$ six sampling sites $\times$ five soil cores $=120$ soil samples. All the sites were selected randomly inside each vegetation belt. Nothofagus betuloides and $N$. pumilio forests were dense in the study area, so soil cores of the bet 1 , bet 2 and pum 1 sites were $0.5-3 \mathrm{~m}$. apart from the nearest tree. Concerning pum2, soil cores were sampled just underneath the trees because $N$. pumilio formed small patches (max $3 \mathrm{~m}$ radius) in the upper alpine belt. Both alpine communities (alp1 and alp2) were under a thick snowpack $(30-100 \mathrm{~cm})$ when sampled, so that their selection was completely random. Due to the harsh field conditions and strong logistic constrains; liquid nitrogen could not be used. During field work in the Darwin

Table 1. Altitudinal ranges, relative elevations and soil depths of the six vegetation belts sampled at Bahia Pia in Cordillera Darwin, Tierra del Fuego (Chile).

\begin{tabular}{|c|c|c|c|c|}
\hline Environment & $\begin{array}{l}\text { Altitude range of the } \\
\text { samples (m a.s.l.) }\end{array}$ & Elevation & $\begin{array}{l}\text { Range of soil cores } \\
\text { depth }(\mathrm{cm})\end{array}$ & Code \\
\hline Nothofagus betuloides forest & $7-83$ & low & $60-30$ & bet1 \\
\hline Nothofagus betuloides forest & $200-304$ & high & $60-10$ & bet2 \\
\hline Nothofagus pumilio forest & $382-473$ & low & $60-4$ & pum1 \\
\hline Dwarf Nothofagus pumilio cover & $566-647$ & high & $20-3$ & pum2 \\
\hline Alpine communities & $356-513$ & low & $60-5$ & alp1 \\
\hline Alpine communities & $566-615$ & high & $10-2$ & alp2 \\
\hline
\end{tabular}




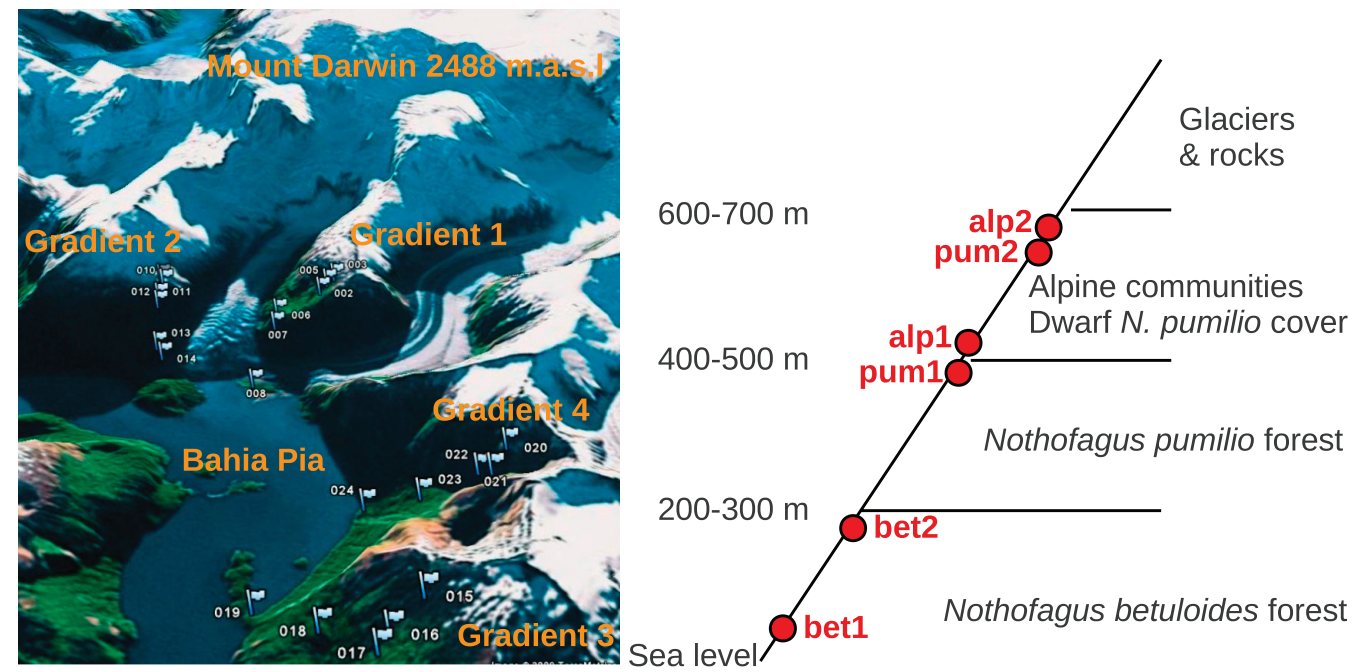

Figure 1. Map of the four transects in the Bahia Pia study area and details of the vegetation belts and their lower and higher sampling sites.

cordillera, all soil samples were sealed in hermetic plastic bags at temperature ranging between 0 and $5^{\circ} \mathrm{C}$ and placed in coolers. Then, during the journey back to Punta Arenas and Santiago de Chile, coolers were stored $72 \mathrm{~h}$ on the boat with ambient temperatures ranging from 5 to $15^{\circ} \mathrm{C}$, which could have affected microbial community compositions prior lab extractions.

\section{Laboratory analyses}

\section{Soil parameters}

A fraction of each of the 120 soil samples was frozen at $-20^{\circ} \mathrm{C}$ until further molecular analysis. A composite soil sample of soil at the site scale was made by mixing the five samples of soil taken in each of the 24 sites. These 24 composite samples were sieved at $2 \mathrm{~mm}$ and visible root material was removed. Soil abiotic properties, namely $\mathrm{pH}$ and gravimetric water content, were measured on fresh soil using standard techniques (Robertson et al. 1999). Soil sub-samples were air dried, ground to a fine powder on a ball-mill, and total $\mathrm{C}$ and $\mathrm{N}$ contents were determined by a C-N analyser. Soils were mainly composed of dead organic materials which were poorly mixed with minerals from non-carbonated bedrock; as such we assume that total $\mathrm{C}$ is a good proxy of total organic $\mathrm{C}$.

The concentration of inorganic $\mathrm{N}\left(\mathrm{NH}_{4}{ }^{+}-\mathrm{N}\right.$ and $\left.\mathrm{NO}_{3}{ }^{-} \mathrm{N}\right)$ in each of the 24 composite soil samples was determined using distillation/titration with $\mathrm{H}_{2} \mathrm{SO}_{4}$ as described in Perez et al. (1998). Briefly, $40 \mathrm{ml}$ of $0.021 \mathrm{~mol}$ $1^{-1} \mathrm{KAl}\left(\mathrm{SO}_{4}\right)_{2}$ were added to $10 \mathrm{~g}$ fresh weight of field moist soil. The solution was shaked for $20 \mathrm{~min}$ and the suspension was filtered. Ten $\mathrm{ml}$ of the filtered solution with $0.3 \mathrm{~g}$ of $\mathrm{MgO}$ was steam distilled to obtain $\mathrm{NH}_{4}{ }^{+}-\mathrm{N}$. Nitrate in the solution was reduced to $\mathrm{NH}_{3}$ by adding $0.7 \mathrm{mg}$ of Legierung Devardas (Perez et al. 1998). Both $\mathrm{NH}_{4}{ }^{+}-\mathrm{N}$ and $\mathrm{NO}_{3}{ }^{-}-\mathrm{N}$ contents were determined through titration with a solution $0.005 \mathrm{~N} \mathrm{H}_{2} \mathrm{SO}_{4}$. Total dissolved nitrogen (TDN) was measured using the persulfate digestion method (Robertson et al. 1999), which allowed calculating the amount of dissolved organic nitrogen $(\mathrm{DON})$ as the difference between TDN and the sum of $\mathrm{NO}_{3}{ }^{-}$and $\mathrm{NH}_{4}{ }^{+}$.
Microbial carbon biomass was assessed using chloroform fumigation- $\mathrm{K}_{2} \mathrm{SO}_{4}$ extraction (Robertson et al. 1999). Briefly, two fresh soil samples (10 g fresh weight) from each site were prepared. One of each paired soil samples was fumigated with $\mathrm{CHCl}_{3}$ for one week in the dark at $25^{\circ} \mathrm{C}$. After removal of the $\mathrm{CHCl}_{3}$, soluble $\mathrm{C}$ and $\mathrm{N}$ were extracted from fumigated and un-fumigated samples with $50 \mathrm{ml}$ of a $0.5 \mathrm{M}$ solution of $\mathrm{K}_{2} \mathrm{SO}_{4}$ for one hour on an orbital shaker. The filtrate was analysed for total dissolved organic $\mathrm{C}$ (TOC) using a TOC analyser. The microbial flush of $\mathrm{C}$ (difference in extractable $\mathrm{C}$ from fumigated and unfumigated samples) was converted to microbial biomass using a $\mathrm{k}_{\mathrm{EC}}$ factor of 0.35 (Robertson et al. 1999). Extractable N was determined by oxidation of $1.5 \mathrm{ml}$ of the filtrate with $4.5 \mathrm{ml} \mathrm{K} \mathrm{S}_{2} \mathrm{O}_{8}$ and resultant $\mathrm{NH}_{4}{ }^{+}-\mathrm{N}$ and $\mathrm{NO}_{3}{ }^{-}-\mathrm{N}$ were determined using autoanalyser procedures. The microbial flush of $\mathrm{N}$ was converted to microbial biomass using a $\mathrm{k}_{\mathrm{EN}}$ factor of 0.18 to correct for incomplete extraction (Robertson et al. 1999). Due to transportation and storage losses, microbial nitrogen and carbon content are available in 19 and 14 sites out of 24 respectively.

\section{Soil microbial communities (PLFA and CE-SSCP)}

Shifts in soil microbial biomass and community structure across elevational gradients were assessed using the phospholipid fatty acid analysis (PLFA) technique (Bardgett and McAlister 1999) on three randomly chosen samples out of the five samples from each site. Briefly, lipids were extracted from $0.5 \mathrm{~g}$ of freeze dried fresh soil (Frostegård et al. 1993). Extracted fatty acid methyl-esters were identified and quantified by chromatograph retention time and mass spectral comparison on a gas chromatograph equipped with a quadrupole mass spectrometer, using standard qualitative bacterial and fungal acid methyl ester mixes ranging from C11 to C20. For each sample, the abundance of individual fatty acid methyl-esters was expressed as mg PLFA $\mathrm{g}^{-1}$ dry soil. The fatty acids i15:0, a15:0, 15:0, i16:0 and i17:0 were used to represent gram-positive bacteria, whereas cy17:0 and cy19:0 were used as indicators of gram-negative bacteria (Frostegard et al. 1993). The unsaturated PLFA $18: 2 \omega 6$ and $10 \mathrm{Me} 16$ were used to represent fungi and 
actinomycetes, respectively. Lastly, the fatty acid 20:4 166 was used as a marker of protozoa (Brant et al. 2006). Indicators of gram-positive bacteria, gram-negative bacteria and actinomycetes were summed to get quantification of bacteria in the soil. The ratio of fungal-to-bacterial PLFAs was calculated as a measure of shifts in the relative abundance of fungi and bacteria in the soil microbial community (Bardgett and McAlister 1999). We acknowledge that PLFA has disadvantages in that individual fatty acids cannot usually be used to identify species, and that samples must be well preserved and analyzed soon after sampling because profiles may change, even with storage at $-70^{\circ} \mathrm{C}$ (Wu et al. 2009). Given the sampling and storage conditions during the present study prior extraction, these limitations may impair our results.

CE-SSCP (capillary electrophoresis - single strand conformational polymorphism) was performed as previously described (Zinger et al. 2008) on the 120 soil samples, i.e. five samples for each site. Briefly, soil DNA extractions were performed with the Power Soil DNA Isolation Kit from ca $150 \mathrm{mg}$ (fresh weight) soil of each of the 120 soil samples. DNA extractions were checked by $1 \%$ agarose gel electrophoresis and DNA concentration was quantified using NanoDrop technologies. We amplified the V3 region of bacterial 16S RNA and the fungal genes using the primers W49 (5'-ACGGTCCAGA CTCCTACGGG-3') and W104-FAM labelled (5'- TTACCG CGGCTGCTGGCAC- $3^{\prime}$ ) and the fungal ITS1 (internal transcribed spacer) region by using ITS5 (5'-GGAAGTAAAAGTCGTAAC AACG-3') (Delbes et al. 2000) and ITS2-HEX labelled (5'- GCTGCGTTCTTCATCGATGC-3') (White et al. 1990). The PCR reactions $(25 \mu \mathrm{l})$ consisted in $2.5 \mathrm{mM}$ of $\mathrm{MgCl} 2,1 \mathrm{U}$ of AmpliTaq GoldTM buffer, $20 \mathrm{~g} \mathrm{l}^{-1}$ of bovine serum albumin, $0.1 \mathrm{mM}$ of each dNTP, $0.26 \mathrm{mM}$ of each primer, $2 \mathrm{U}$ of AmpliTaqGold DNA polymerase and $10 \mathrm{ng}$ of DNA template. The PCR reaction was carried out as follows: an initial step at $95^{\circ} \mathrm{C}(10 \mathrm{~min})$, followed by 30 cycles at $95^{\circ} \mathrm{C}(30 \mathrm{~s}), 56^{\circ} \mathrm{C}(15 \mathrm{~s})$ and $72^{\circ} \mathrm{C}(20 \mathrm{~s})$, and final step at $72^{\circ} \mathrm{C}(7 \mathrm{~min})$, for bacteria, and an initial step at $95^{\circ} \mathrm{C}(10 \mathrm{~min})$, followed by 33 cycles at $95^{\circ} \mathrm{C}(30 \mathrm{~s}), 54^{\circ} \mathrm{C}(15 \mathrm{~s})$ and $72^{\circ} \mathrm{C}(30 \mathrm{~s})$, and a final step at $72^{\circ} \mathrm{C}(7 \mathrm{~min})$ for fungi. All PCR products were checked by $1.6 \%$ agarose gel electrophoresis and DNA concentration was quantified. Community molecular fingerprint were obtained by submitting amplicons of each sample to CE-SSCP on a genetic analyzer. CE-SSCP profiles corresponded to sorted single DNA strains according to their conformation, length and nucleotidic composition which fluorescence indicated abundance. CE-SSCP profiles were visually checked individually and normalized prior to statistical analysis (Geremia and Zinger 2012). It is important to keep in mind that capillary electrophoresissingle strand conformational polymorphism gives a community 'fingerprint' and not individual sequences.

\section{Statistical analyses}

All data were carried on with $\mathrm{R}$ ver. 2.14.1.

\section{Univariate analyses}

Differences in soil chemical and biological parameters according to vegetation belt and relative altitude were analysed using linear mixed effects models (function 'Ime' of the 'nlme' package). Vegetation belt (three levels: $N$. betuloides, $N$. pumilio and alpine belt) and relative altitude (higher $v s$. lower elevation within the belt) nested within vegetation belt were defined as fixed factors and transect was included as random factor to take into account the observational design. All soil parameters were analysed separately. To achieve the assumptions of normality, $\mathrm{N}-\mathrm{NH}_{4}{ }^{+}$and $\mathrm{N}_{-} \mathrm{NO}_{3}{ }^{-}$concentrations, soil $\mathrm{N}$ and $\mathrm{C}$ content, soil $\mathrm{C}: \mathrm{N}$ ratio and biological parameter (biomass of fungi, bacteria, protozoa and actinomycetes, microbial $\mathrm{C}$ and $\mathrm{N}$ contents, microbial $\mathrm{C}: \mathrm{N}$ ratio) were squareroot transformed whereas soil water content, total dissolved nitrogen and dissolved organic nitrogen were logtransformed. Soil $\mathrm{pH}$, soil fungi:bacteria ratio and the total amount of micro-organisms did not need transformation to achieve the assumption of normality.

\section{Multivariate analyses}

Multivariate analyses were used to get an overview of relationships between chemical and biological properties, as well as to look at the effects of soil chemical properties on fungal and bacterial communities. Since soil properties might be highly correlated, a principal component analysis (PCA) was performed to reduce the number of soil parameters (using the 'PCA' function of the 'FactoMineR' package). This PCA led to the selection of five soil parameters that were used in redundancy analyses (RDA) to analyse the effects of soil properties on bacterial and fungal communities. To test for the effect of vegetation belt and relative altitude on the microbial composition (as given by the results of PLFA analyses), and on bacterial and fungal communities (as given by the SSCP analyses), we performed redundancy analyses (using 'rda' function of the 'vegan' package) on each of the three matrices constrained by vegetation belt and relative altitude nested within vegetation belt, specifying the transect as a covariate to take into account the observational design. The effects of soil parameters on the microbial composition and on bacterial and fungal communities were analysed through redundancy analyses that constrained each of the three matrices by the PCA-selected soil parameters, specifying vegetation belt and relative altitude within vegetation belt as a covariate. Backward selections were performed on the entire model to select for the best model based on the lowest AIC. Permutation tests were used to assess the significance of these multivariate regression models. Pearson correlations were then performed to test for correlations between selected significant soil parameters and microbial composition (i.e. total microbial biomass, biomass of bacteria, protozoa and fungi, and fungi:bacteria ratio, as given by the results of PLFA analyses).

\section{Results}

\section{Effect of vegetation belt and relative altitude on soil parameters}

Soil $\mathrm{pH}, \mathrm{N}-\mathrm{NO}_{3}{ }^{-}$, dissolved organic nitrogen (DON) and total dissolved nitrogen (TDN), microbial C content and microbial $\mathrm{C}: \mathrm{N}$ ratio did not vary significantly across 
Table 2. Results of linear mixed effects model testing the effects of vegetation belt and relative altitude within vegetation belt (fixed effects) according to the transect (random effect) on soil abiotic and biotic parameters. Significant values $(p<0.05)$ are listed in bold.

\begin{tabular}{|c|c|c|c|c|c|c|c|}
\hline & \multicolumn{7}{|c|}{ Linear mixed effects models results } \\
\hline & $\mathrm{DF}$ & F-value & $p$-value & & DF & F-value & $\mathrm{p}$-value \\
\hline Soil water content & & & & $\mathrm{NH} 4{ }^{+}$content & & & \\
\hline Vegetation belt & 2 & 4.021 & 0.040 & $\overline{\text { Vegetation belt }}$ & 2 & 3.952 & 0.042 \\
\hline Vegetation/altitude & 3 & 0.042 & 0.989 & Vegetation/altitude & 3 & 4.644 & 0.017 \\
\hline Residuals & 15 & & & Residuals & 15 & & \\
\hline $\mathrm{pH}$ & & & & $\mathrm{NO}_{3}{ }^{-}$content & & & \\
\hline Vegetation belt & 2 & 2.606 & 0.107 & Vegetation belt & 2 & 0.851 & 0.447 \\
\hline Vegetation/altitude & 3 & 0.767 & 0.530 & Vegetation/altitude & 3 & 0.678 & 0.579 \\
\hline Residuals & 15 & & & Residuals & 15 & & \\
\hline Soil C content & & & & Dissolved organic N & & & \\
\hline$\overline{\text { Vegetation belt }}$ & 2 & 4.601 & 0.028 & Vegetation belt & 2 & 1.975 & 0.181 \\
\hline Vegetation/altitude & 3 & 0.402 & 0.754 & Vegetation/altitude & 3 & 1.213 & 0.347 \\
\hline Residuals & 15 & & & Residuals & 12 & & \\
\hline$\underline{\text { Soil N content }}$ & & & & Microbial C content & & & \\
\hline Vegetation belt & 2 & 4.063 & 0.039 & Vegetation belt & 2 & 1.654 & 0.281 \\
\hline Vegetation/altitude & 3 & 0.242 & 0.865 & Vegetation/altitude & 3 & 0.734 & 0.575 \\
\hline Residuals & 15 & & & Residuals & 15 & & \\
\hline Soil C:N & & & & Microbial N content & & & \\
\hline$\overline{\text { Vegetation belt }}$ & 2 & 7.729 & 0.005 & $\overline{\text { Vegetation belt }}$ & 2 & 4.297 & 0.045 \\
\hline Vegetation/altitude & 3 & 8.999 & 0.001 & Vegetation/altitude & 3 & 0.235 & 0.87 \\
\hline Residuals & 15 & & & Residuals & 10 & & \\
\hline Total dissolved N & & & & Microbial C: $\mathrm{N}$ ratio & & & \\
\hline Vegetation belt & 2 & 2.465 & 0.119 & Vegetation belt & 2 & 1.04 & 0.419 \\
\hline Vegetation/altitude & 3 & 1.424 & 0.275 & Vegetation/altitude & 3 & 1.025 & 0.456 \\
\hline Residuals & 15 & & & Residuals & 5 & & \\
\hline
\end{tabular}

vegetation belts or between altitudes within vegetation belt (Table 2, Fig. 2). Within forest, soil water content, soil total $\mathrm{N}$, soil total $\mathrm{C}$ and microbial $\mathrm{N}$ contents were higher under Nothofagus pumilio than under $N$. betuloides, though there was no significant difference between either of these and alpine vegetation. $\mathrm{NH}_{4}^{+}$ content was higher in $N$. pumilio forests than in the alpine belt (Table 2, Fig. 2). Within each belt, $\mathrm{NH}_{4}^{+}$ content was overall significantly lower at higher altitude (Table 2) although it was not statistically significant
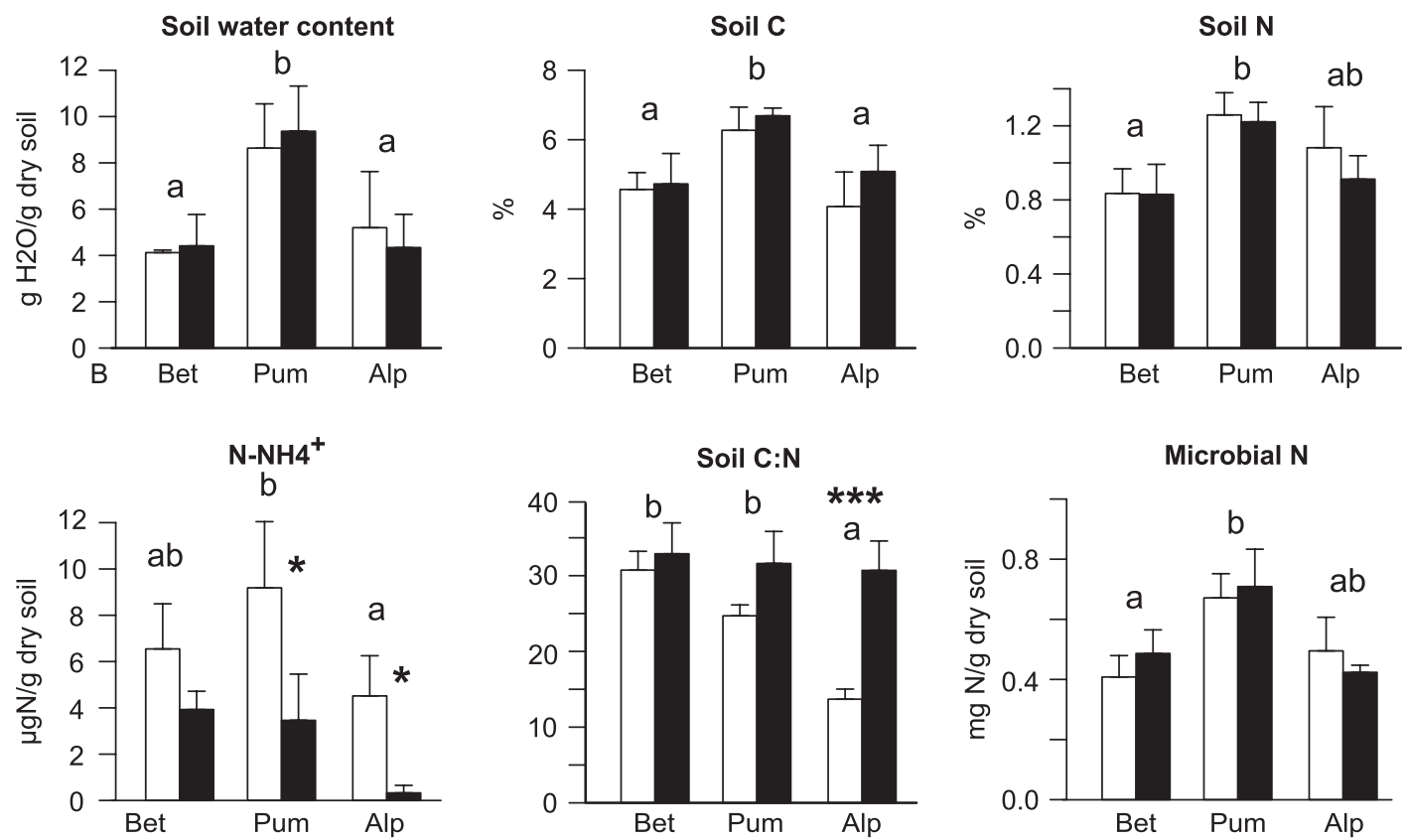

Figure 2. Means $( \pm \mathrm{SE}$ ) of soil chemical parameters according to vegetation belt type (Nothofagus betuloides "Bet", Nothofagus pumilio "Pum" and alpine vegetation "Alp") and elevation (lower (white) versus higher (black) elevation). Significant differences between vegetation belts are indicated with different letters (according to Tukey post hoc tests) and significant differences between elevation within vegetation belts are indicated as ${ }^{*} \mathrm{p}<0.05,{ }^{*} \mathrm{p}<0.01,{ }^{*} * *_{\mathrm{p}}<0.001$. 
within $N$. betuloides forests (Fig. 2). Lastly, soil C:N ratios were affected both by vegetation belt and relative altitude within vegetation belt overall (Table 2). First, despite significant differences between the three vegetation belts in soil C:N ratios at lower altitudes, this pattern was not observed for the higher altitudes where soil C:N ratios reached 30 in all vegetation types. Second, soil C:N ratios were significantly higher at upper altitude under alpine vegetation, whereas there was no significant difference between lower and higher elevation under $N$. pumilio and $N$. betuloides forests.

\section{Effect of vegetation belt, altitude and soil parameters on soil biota abundance and composition}

Total soil microbial biomass did not significantly differ between vegetation belts or relative altitudes (Fig. 3a), probably because neither protozoa, nor bacteria or fungi biomass differed consistently between vegetation belts and relative altitude within vegetation belts (Fig. 3b-d). However, upper sites of alpine vegetation had significantly lower bacterial biomass than alpine sites at lower elevation (Fig. 3b), and biomass of protozoa was significantly higher at higher elevation in $N$. pumilio forests (Fig. 3c). The fungi:bacteria ratio was similar across vegetation belts $\left(F_{2,14}=0.336, p=0.720\right)$, but within each vegetation belt the fungi:bacteria ratio was higher at higher altitude $\left(\mathrm{F}_{3,14}=3.541, \mathrm{p}=0.043\right)$, and this was particularly noticeable in alpine sites (Fig. 3e). Regardless of vegetation belt, bacteria dominated over fungi at lower altitude (fungi:bacteria $<1$ ) whereas fungi dominated at higher elevation (fungi:bacteria $>1$ ).

The principal component analysis on soil chemical and biological parameters (Supplementary material Appendix 1 Fig. A1) showed that both microbial $\mathrm{N}$ and microbial $\mathrm{C}$ contents were strongly correlated to soil $\mathrm{N}$ contents $\quad\left(t_{1,17}=5.540, p<0.001\right.$ and $t_{1,12}=5.235$, $\mathrm{p}<0.001$ respectively), soil $\mathrm{C}$ contents $\left(\mathrm{t}_{1,17}=4.689\right.$, $\mathrm{p}<0.001$ and $\mathrm{t}_{1,12}=5.881, \mathrm{p}<0.001$ resp.) and soil water contents $\left(t_{1,17}=6.701, \quad p<0.001\right.$ and $t_{1,12}=5.541$, $\mathrm{p}<0.001$ resp.), but not with soil C: $\mathrm{N}$ ratios $\left(\mathrm{t}_{1,17}=-0.658\right.$, $\mathrm{p}=0.519$ and $\mathrm{t}_{1,12}=-0.186, \mathrm{p}=0.856$ resp.). Microbial $\mathrm{N}$ contents were also correlated to soil total dissolved $\mathrm{N}$ $\left(\mathrm{t}_{1,17}=2.199, \mathrm{p}=0.042\right)$ and soil $\mathrm{NO}_{3}{ }^{-}$contents $\left(\mathrm{t}_{1,17}=2.162, \mathrm{p}=0.044\right)$. According to these correlation patterns soil parameters were reduced to $\mathrm{pH}, \mathrm{NH}_{4}{ }^{+}$content, total dissolved $\mathrm{N}$ content (TDN), soil $\mathrm{N}$ content and soil C: $\mathrm{N}$ ratio, for further explanatory analyses of variations in microbial communities linked to soil properties as assessed by redundancy analyses.

The soil community functional structure, as reflected by PLFA, was neither affected by the vegetation belt nor (a)
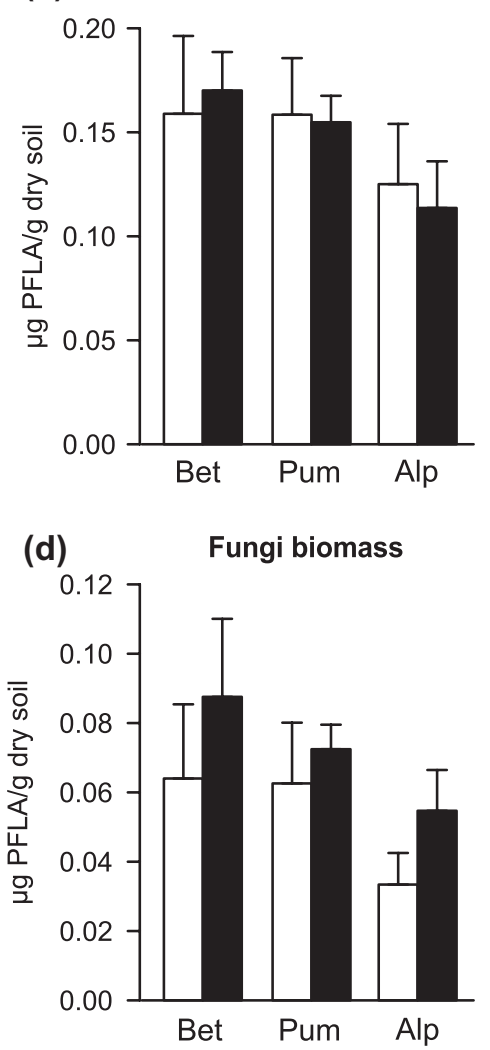

(b)

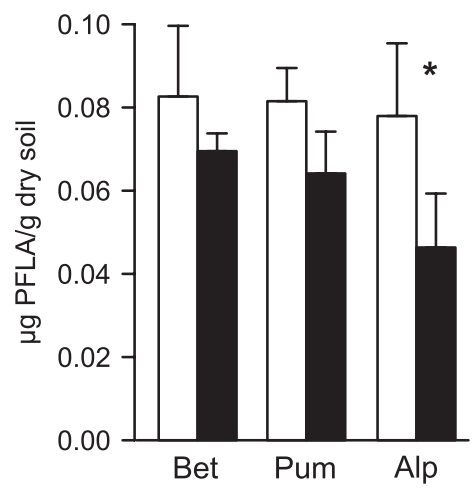

(e)

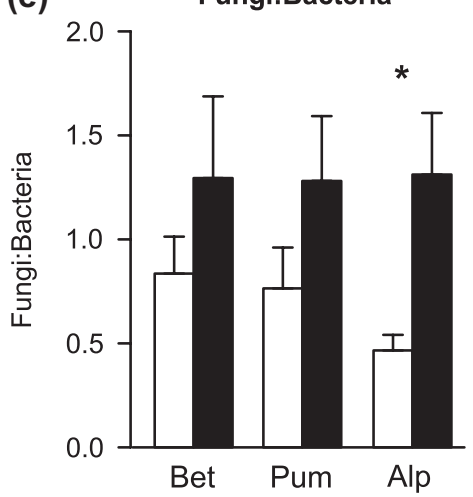

(c) Protozoa biomass

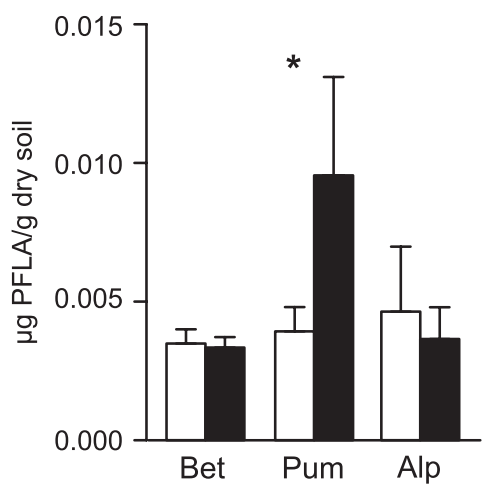

Figure 3. Means ( \pm SE) of soil total microbial biomass (a), soil biomasses of bacteria (b), protozoa (c) and fungi (d) and fungi:bacteria ratio (e) according to vegetation belt type (Nothofagus betuloides "Bet", Nothofagus pumilio "Pum" and alpine vegetation "Alp") and elevation (lower (white) versus higher (black) elevation). Significant differences between vegetation belts are indicated with different letters (according to Tukey post hoc tests) and significant differences between elevation within vegetation belts are indicated as $*_{\mathrm{p}}<0.05$, $* * \mathrm{p}<0.01$, $* * * \mathrm{p}<0.001$. 
Table 3. Results of permutations tests (based on 999 Monte Carlo permutations) on redundancy analyses constraining soil biota structure, soil bacterial composition and soil fungal composition matrices by (a) vegetation belt and relative altitude within vegetation belt or (b) selected soil parameters. The sampling design has been taken into account by adding the transect as a covariate when testing for effect of vegetation belt and relative altitude. In addition, to test for effect of soil parameters per se, vegetation type and relative altitude within vegetation type have been added as a covariate in these models. Significant values $(p<0.05)$ are listed in bold.

\begin{tabular}{|c|c|c|c|c|c|}
\hline Response matrix & Constraining factor & Covariable & DF & F-value & $\mathrm{p}$-value \\
\hline \multirow[t]{10}{*}{ Soil biota structure (PLFA) } & vegetation & transect & 2 & 1.596 & 0.161 \\
\hline & vegetation/altitude & & 3 & 1.697 & 0.132 \\
\hline & residuals & & 14 & & \\
\hline & soil parameters & vegetation/altitude & 5 & 2.978 & 0.015 \\
\hline & residuals & & 12 & & \\
\hline & soil parameters (best model) & vegetation/altitude & 2 & 7.972 & 0.001 \\
\hline & residuals & & 20 & & \\
\hline & total dissolved $\mathrm{N}$ & vegetation/altitude & 1 & 9.568 & 0.010 \\
\hline & soil $\mathrm{C}: \mathrm{N}$ & & 1 & 6.377 & 0.010 \\
\hline & residuals & & 20 & & \\
\hline \multirow[t]{7}{*}{ Bacterial communities (SSCP) } & vegetation & transect & 2 & 0.936 & 0.529 \\
\hline & vegetation/altitude & & 3 & 0.779 & 0.797 \\
\hline & residuals & & 15 & & \\
\hline & soil parameters & vegetation/altitude & 5 & 0.971 & 0.522 \\
\hline & residuals & & 13 & & \\
\hline & absolute altitude & transect & 1 & 0.489 & 0.943 \\
\hline & residuals & & 19 & & \\
\hline \multirow[t]{9}{*}{ Fungal communities (SSCP) } & vegetation/altitude & transect & 5 & 1.323 & 0.020 \\
\hline & residuals & & 14 & & \\
\hline & vegetation & transect & 2 & 1.755 & 0.002 \\
\hline & vegetation/altitude & & 3 & 1.035 & 0.396 \\
\hline & residuals & & 14 & & \\
\hline & soil parameters & vegetation/altitude & 5 & 0.923 & 0.661 \\
\hline & residuals & & 16 & & \\
\hline & absolute altitude & transect & 1 & 2.078 & 0.008 \\
\hline & residuals & & 18 & & \\
\hline
\end{tabular}

by relative altitude within vegetation belt (Table 3). However, soil biota structure varied significantly with total dissolved $\mathrm{N}$ and soil C:N ratio (Table 3, best model). There were overall more biota (Table 4), and especially more bacteria and protozoa, in soils with higher levels of total dissolved $\mathrm{N}$, whereas fungi were more abundant and bacteria less abundant in soils with higher C:N ratios, leading to a greater fungi:bacteria ratio (Table 4).

In terms of composition, bacterial communities were affected neither by vegetation belt nor by relative altitude within vegetation belt, or by soil parameters and absolute altitude (Table 3). In contrast, the three vegetation belts and different absolute altitudes hosted significantly different fungal communities, but within vegetation belts, there was no significant difference according to relative altitude (Table 3). As for bacterial communities, fungal community composition was not affected by soil parameters (Table 3).

\section{Discussion}

In southern Patagonia, at the upper range of Cordillera Darwin, one can assume that the current treeline is driven only by natural factors because human activities and atmospheric $\mathrm{N}$ deposition are extremely reduced. In such a context, our study is useful to approach key mechanisms limiting altitudinal expansion of trees.

\section{Changes in soil abiotic parameters in response to vegetation and elevation}

Soils of Nothofagus forests of the Cordillera Darwin were characterized by statistically contrasted C:N ratios and distinct water contents, $\mathrm{NH}_{4}{ }^{+}$, total $\mathrm{C}$ and $\mathrm{N}$, and microbial $\mathrm{N}$ (Table 2). Since soil water content, $\mathrm{NO}_{3}{ }^{-}$and $\mathrm{NH}_{4}{ }^{+}$ contents are subject to strong temporal variability, their explanatory power, when looked at individually, might

Table 4. Pearson correlation coefficients between main soil drivers (i.e. soil pH, soil total dissolved $\mathrm{N}$, soil $\mathrm{NH}_{4}{ }^{+}$content, soil $\mathrm{N}$ and soil C:N) and soil biota structure measured through biomasses of bacteria, protozoa and fungi, total microbial biomass and soil fungi: bacteria ratio. Significant correlation $(\mathrm{p}<0.05)$ between soil parameter and biota structure are in bold and indicated as *p $<0.05$, $* * p<0.01, * * * p<0.001$.

\begin{tabular}{|c|c|c|c|c|c|}
\hline & Bacteria & Protozoa & Fungi & Total biomass & Fungi:bacteria \\
\hline $\mathrm{pH}$ & 0.266 & 0.423 & -0.045 & 0.128 & -0.098 \\
\hline \multicolumn{6}{|l|}{ Total dissolved } \\
\hline $\mathrm{N}$ & $0.753^{* * *}$ & $0.506^{* *}$ & 0.300 & $0.631^{* *}$ & 0.139 \\
\hline $\mathrm{N}-\mathrm{NH}_{4}{ }^{+}$ & $0.556^{* *}$ & 0.065 & 0.300 & $0.502 *$ & 0.105 \\
\hline Soil $N^{+}$ & 0.401 & 0.421 & 0.110 & 0.318 & 0.142 \\
\hline Soil C:N & $-0.420^{*}$ & 0.027 & $0.410^{*}$ & 0.048 & $0.686^{* * *}$ \\
\hline
\end{tabular}


be limited in our study where we only could undertake a one-time sampling due to the remote location of the study sites. Yet, Nothofagus pumilio soils at $400-500 \mathrm{~m}$ (i.e. pum1) displayed highest $\mathrm{NH}_{4}{ }^{+}$and water contents, which were likely to be related because elevated soil moisture may restrict nitrification activities (Bardgett 2005). In contrast, soil $\mathrm{pH}$, total dissolved $\mathrm{N}$, soil C: $\mathrm{N}$ as well as total $\mathrm{C}$ and $\mathrm{N}$ contents are steadier with time, and could be considered as fingerprints of the ecosystem functioning since they integrate dominant vegetation traits and decomposition features as well as geomorphological and micro-climatic characteristics. Here, soil C:N differed between vegetation belts at their lowest altitude (i.e. bet1, pum1, alp1), but not anymore when located at the highest elevation (bet2, pum2, alp2). This suggests that any potential effects of changes in tree litter quality and/or decomposers leading to decreasing decomposition with altitude within a single forest type (pum or alp) were possibly compensated by the positive effects of other variables (soil moisture, metabolic activities, microbial communities...) at its upper limits. Within Nothofagus forests of the Cordillera Darwin, $N$. pumilio soils contained more total soil $\mathrm{N}$ and $\mathrm{C}$ contents, and more microbial $\mathrm{N}$ than $N$. betuloides soils, whereas nitrate and ammonium contents were not different between both forest types. The deciduous leaves of $N$. pumilio are likely to represent a larger flux of $\mathrm{N}$ and $\mathrm{C}$ to the forest floor than in the evergreen forest of $N$. betuloides, where $\mathrm{N}$ and $\mathrm{C}$ are retained aboveground. These stronger fluxes of $\mathrm{N}$ and $\mathrm{C}$ combined with high non-structural carbohydrates contents in deciduous leaves of $N$. pumilio (Fajardo et al. 2013) and strong $\mathrm{N}$-resorption (Diehl et al. 2003), could favour the accumulation of $\mathrm{C}$ and refractory- $\mathrm{N}$ in soils. Overall, these higher soil $\mathrm{N}$ and $\mathrm{C}$ contents also suggest that under $N$. pumilio cover decomposition of plant litter and mineralization of soil organic matter could be limited (Barrera et al. 2000, Caldentey et al. 2001). This could result from the significantly higher soil water content measured at our sites under $N$. pumilio that, in combination with cold temperatures and low $\mathrm{pH}$, would limit decomposers activities at the treeline (Körner and Paulsen 2004, Romanya et al. 2005). Another plausible explanation could be that deciduous $N$. pumilio litter decomposed slowly due to higher litter contents in refractory $\mathrm{C}$ and $\mathrm{N}$-compounds (Hättenschwiler and Vitousek 2000, Diehl et al. 2003). This hypothesis concurs with our observations of the highest microbial $\mathrm{N}$ and total soil $\mathrm{N}$ contents for $N$. pumilio consistently along its range when compared to the other two vegetation belts. Since microbial $\mathrm{N}$ or C:N ratios could be considered as intermediate in their capacity to express temporal or spatial variations in ecosystems functioning, this relationship between microbial $\mathrm{N}$ and total $\mathrm{N}$ in $N$. pumilio soils towards the treeline at our sites suggests a greater $\mathrm{N}$ sequestration capacity through its immobilization, biotic (microbial) (Schmidt et al. 1999) and/or abiotic (SOM) (Baptist et al. 2008). Indeed, such $\mathrm{N}$ immobilization could result simultaneously from a litter rich in refractory $\mathrm{C}$ and $\mathrm{N}$-compounds and from a competitive microbial community under $N$. pumilio cover. Our results also tend to confirm, in such a pristine context, that krummholz lenga stands are nutrient-rich forests that act as nutrient sinks due to functional advantages at the treeline (Barrera et al. 2000, Frangi et al. 2005). However, supplemental data are required to confirm the observed patterns, such as chemistry of litter and above-ground fresh plant tissues, as well as litter decomposition surveys, for each vegetation belt and altitude.

\section{Changes in microbial communities in response to vegetation and elevation}

Total microbial biomass (bacteria, protozoa and fungi) did not vary significantly across vegetation belts encompassing the treeline when sampling occurred (Fig. 3a). Despite such constant biomass, fungal community composition did change along the elevational gradient and concomitant changes in vegetation types as hypothesised (Table 3). These results confirm recent findings from a montane elevational gradient in eastern Peru (Fierer et al. 2011) according to which the composition of microbial community changes with elevation even though microbial diversity is independent of altitude. Although not in the context of the treeline, the influence of elevation on soil fungal communities has also been recently observed in the case of Silene acaulis cushions (Roy et al. 2013). By contrast to fungal communities, bacterial communities did not differ along the elevational gradient (Table 3). According to recent results, bacterial and fungal communities have different responses to local site characteristics, with bacteria being primarily influenced by soil $\mathrm{pH}$ (Fierer and Jackson 2006, Roy et al. 2013) while fungi respond mainly to plant-related variables, such as soil organic matter quality or annual radiation (Zinger et al 2011). Thus, at our study site, the consistency of soil $\mathrm{pH}$ among the three vegetation types could explain the constant bacterial community composition at the treeline (Fig. 2). By contrast, the change in fungal community composition could be linked to the decrease in the soil C: $\mathrm{N}$ ratio along the vegetation gradient towards the treeline (i.e. from bet to alp, Fig. 2). Furthermore, soil C:N was strongly correlated to the fungi:bacteria ratio (Table 4) across all vegetation belts with fungi dominating over bacteria in soils with high C:N ratio regardless of the vegetation belt. By contrast, bacterial biomass was correlated to the amount in total dissolved nitrogen (TDN, Table 4), mainly $\mathrm{N}-\mathrm{NH}_{4}{ }^{+}$, which tended to be higher at lower elevation in $N$. pumilio and alpine vegetation belts (Fig. 2). Indeed, at lower elevation, higher amounts of inorganic $\mathrm{N}$ were associated with bacteria-dominated microbial community (ratio fungi:bacteria $<1$ ) whereas at higher elevation, high soil C:N was associated with the predominance of a fungidominated microbial community (ratio fungi:bacteria $>1$ ). These results are in line with our hypothesis and confirmed our expectations that increasing elevation is paralleled by a reduction in soil inorganic $\mathrm{N}$ content and by an increase in soil C: $\mathrm{N}$ ratio, while microbial community composition changes with fungal communities becoming dominant. These outcomes, specific to a treeline area in a pristine context, are also consistent with previous studies showing a declining nutrient availability with elevation (Sundqvist et al. 2011), and a fungal-based 
microbial community associated with reduced nutrient availability (van der Heijden et al. 2008, Sundqvist et al. 2011). At our site focusing on the treeline area, the simultaneous decrease in soil $\mathrm{N}-\mathrm{NH}_{4}{ }^{+}$and the increases in soil $\mathrm{C}: \mathrm{N}$ and fungi:bacteria ratios with elevation within vegetation belts were stronger in alpine vegetation than under Nothofagus forests. These differences in below-ground properties and the responses of these properties to elevation between vegetation covers concur with the conclusions from Swedish subarctic tundra (Sundqvist et al. 2011). They indicate that responses of soil microbial communities to elevation could be influenced by functional properties of forest communities (Sundqvist et al. 2013) for instance through variations in litter quality or in soil moisture (Fajardo et al. 2013). Finally, changes in soil biota composition according to elevation within vegetation belts coincided mainly with changes in soil inorganic nitrogen (i.e. $\mathrm{NH}_{4}^{+}$) contents at the treeline, which suggest interplay between vegetation type, soil biota and soil nitrogen availability. However, despite these quantitative changes in soil biota, we did not find any significant direct relationships between bacterial or fungal community composition and soil parameters.

\section{Resource partitioning at treeline between microbes and plants}

We observed a number of consistent patterns of change between lower and higher altitude within the three vegetation belts that supported our hypothesis of simultaneous $\mathrm{N}$ availability and microbial community variations. Increasing elevation was associated with a decrease in soil $\mathrm{N}-\mathrm{NH}_{4}{ }^{+}$content for the $N$. pumilio and the alpine belt, and an increase in soil $\mathrm{C}: \mathrm{N}$ ratio combined with higher fungi:bacteria ratio under the alpine belt. As already mentioned, all soils were essentially composed of organic materials poorly mixed with minerals from non-carbonated bedrocks. Consequently, these organic soils represent the major substrate for heterotrophic microbial communities, and soil $\mathrm{C}: \mathrm{N}$ ratio can be considered as the $\mathrm{C}: \mathrm{N}$ ratio of their organic substrate. At the highest altitude of the three vegetation types, soil/substrate $\mathrm{C}: \mathrm{N}$ reached 30 , which is considered as a threshold that determines whether microbes are $\mathrm{C}$ limited $(\mathrm{C}: \mathrm{N}<30)$ or $\mathrm{N}$ limited $(\mathrm{C}: \mathrm{N}>30)$ during organic matter breakdown (Kaye and Hart 1997). Therefore, at higher elevation in the alpine belt, high values of soil $\mathrm{C}: \mathrm{N}$ ratio suggest that microbes become increasingly $\mathrm{N}$ limited, potentially favouring $\mathrm{N}$ immobilization of exogenous sources of inorganic $\mathrm{N}$ and slowing down litter decomposition. Although not significant in our study, we measured increased soil C:N ratio with elevation within $N$. pumilio forests, which has already been observed in southern Patagonia (Frangi et al. 2005). At its lowest elevation, alpine vegetation had a lower soil $\mathrm{C} / \mathrm{N}$ ratio than both forests, which could result from the absence of coarse woody debris, resulting in a lower input of recalcitrant carbon in litter.

Overall, higher soil C: $\mathrm{N}$ ratio at higher altitude would favour $\mathrm{N}$ immobilization over $\mathrm{N}$ mineralization, therefore contributing to the decrease in soil $\mathrm{NH}_{4}{ }^{+}$content through a reduction in its production and an increase in its immobilization. Under such conditions, we suspect strong competition between trees and microbes to occur for available inorganic $\mathrm{N}$ forms as found in peatlands (Bragazza et al. 2013). However, direct measurements of $\mathrm{N}$ resource partitioning between soil microbes and vegetation, for instance using ${ }^{15} \mathrm{~N}$ tracers (Legay et al. 2013), remain necessary to conclude on this competition along this altitudinal gradient and within vegetation belts. In Darwin Cordillera, since microbial nitrogen and microbial carbon biomass was constant along the elevation gradient within vegetation belts (Table 2, Fig. 2); we can assume that microbes were not nutrient limited even at higher altitude. Consequently, we propose that in these upper stressful limits, soil microbial communities are more competitive than trees to take up soil $\mathrm{N}$, and the relatively low residual amount of soil inorganic $\mathrm{N}$ available for trees could participate to their establishment limitation, leading to treeline formation. The density of root network of $N$. pumilio in high elevation sites (Ibanez unpubl.) also argues in favour of strong competition for limited $\mathrm{N}$ resources (Hertel and Scholing 2011). Indeed, this increase in biomass and density of the fine root system at the treeline may enlarge the volume of the prospected soil, and could indicate an adaptation of the trees to the harsh soil conditions including substrate thinness, steepness and limited nutrient availability.

\section{Conclusion}

Taking advantage of a mountaineering expedition in highly remote Cordillera Darwin during the mid austral spring of 2009 , we conducted an observational study of soils parameters and microbial communities' structure and composition along an elevation gradient. In the Darwin Cordillera where the current treeline is assumed to be strictly driven by natural factors, we found that elevation was linked to a decrease in $\mathrm{NH}_{4}^{+}$availability, to an increase in soil C:N ratio and to a change in microbial community structure towards a fungal-dominated community in the alpine vegetation belt. Lower vegetation belts $(N$. betuloides and $N$. pumilio) exhibited more complex patterns, but our results illustrate only a snapshot of an ecological setting subjected to many short and long-term variations. The shift towards a fungal dominated community observed in the alpine vegetation belt could favour $\mathrm{N}$ immobilization over $\mathrm{N}$ mineralization, potentially leading to a competition between trees and soil microbial communities for limited soil inorganic $\mathrm{N}$. In these stressful alpine environments, we hypothesize that microbes are more competitive than trees for $\mathrm{N}$ uptake, and the residual low amount of inorganic $\mathrm{N}$ available for trees in the soil could participate to the establishment limitation. Together, these results suggest $\mathrm{N}$ limitations at upper limits of forest distributions in pristine alpine regions such as the Darwin Cordillera, but additional measurements through the growing season and data on litter and above-ground fresh plant tissues chemistry and decomposition within each vegetation belt and along the altitudinal gradient are needed to support our interpretations. In human-impacted alpine areas such as in central Europe, $\mathrm{N}$ is often less limiting and other factors (i.e. growth limitation hypothesis) might be dominant in the control of the treeline. By highlighting potential detailed mechanisms associated with changes in the structure of 
microbial, and especially fungal communities, and with tree - microbe competition for scarce mineral $\mathrm{N}$ resources, our results open new avenues for novel research at treelines around the world.

Acknowledgements - This research was conducted as part of the 'Un Rêve de Darwin' project, with funding from CNRS. AT is grateful to Marlene Manzano and Sylvain Faugeron for technical and logistical assistance in Chile. We thank Florence Baptist for discussions on sampling protocols and Hanna Secher-Frommell, Cindy Arnoldi and Laurent Grasset for assistance with lab analyses.

\section{References}

Aravena, J. C. et al. 2002. Tree-ring growth patterns and temperature reconstruction from Nothofagus pumilio (Fagaceae) forests at the upper tree line of southern Chilean Patagonia. - Rev. Chil. Hist. Nat. 75: 36-76.

Baptist, F. et al. 2008. Tannin impacts on microbial diversity and the functioning of alpine soils: a multidisciplinary approach. - Environ. Microbiol. 10: 799-809.

Baptist, F. et al. 2010. Direct and indirect control by snow cover over decomposition in alpine tundra along a snowmelt gradient. - Plant Soil 328: 397-410.

Bardgett, R. D. 2005. The biology of soil: a community and ecosystem approach. - Oxford Univ. Press.

Bardgett, R. D. and McAlister, E. 1999. The measurement of soil fungal : bacterial biomass ratios as an indicator of ecosystem self-regulation in temperate meadow grasslands. - Biol. Fertil. Soils 29: 282-290.

Barrera, M. D. et al. 2000. Structural and functional changes in Nothofagus pumilio forests along an altitudinal gradient in Tierra del Fuego, Argentina. - J. Veg. Sci. 11: 179-188.

Bragazza, L. et al. 2013. Biogeochemical plant-soil microbes feedback in response to climate warming in peatlands. - Nat. Climate Change 3: 273-277.

Brant, J. B. et al. 2006. Root controls on soil microbial community structure in forest soils. - Oecologia 148: 650-659.

Caldentey, J. et al. 2001. Litter fluxes and decomposition in Nothofagus pumilio stands in the region of Magallanes, Chile. - For. Ecol. Manage. 148: 145-157.

Cuevas, J. G. 2000. Tree recruitment at the Nothofagus pumilio alpine timberline in Tierra del Fuego, Chile. - J. Ecol. 88: 840-855.

Cullen, L. E. et al. 2001. Climate change and tree-ring relationships of Nothofagus menziesii tree-line forests. - Can. J. For. Res. Rev. Can. Rech. For. 31: 1981-1991.

Delbes, C. et al. 2000. Monitoring of activity dynamics of an anaerobic digester bacterial community using 16S rRNA polymerase chain reaction - single-strand conformation polymorphism analysis. - Environ. Microbiol. 2: 506-15.

Diehl, P. et al. 2003. Nutrient conservation strategies in native Andean-Patagonian forests. - J. Veg. Sci. 14: 63-70.

Fajardo, A. et al. 2013. Similar variation in carbon storage between deciduous and evergreen treeline species across elevational gradients. - Ann. Bot. 112: 623-631.

Fierer, N. and Jackson, R. B. 2006. The diversity and biogeography of soil bacterial communities. - Proc. Natl Acad. Sci. USA 103: 626-631.

Fierer, N. et al. 2011. Microbes do not follow the elevational diversity patterns of plants and animals. - Ecology 92: 797-804.

Frangi, J. L. et al. 2005. Nutrient cycling in Nothofagus pumilio forests along an altitudinal gradient in Tierra del Fuego, Argentina. - For. Ecol. Manage. 217: 80-94.
Frostegård, A. et al. 1993. Shifts in the structure of soil microbial communities in limed forests as revealed by phospholipid fatty-acid analysis. - Soil Biol. Biochem. 25: 723-730.

Geremia, R. A. and Zinger, L. 2012. Molecular fingerprinting of fungal communities in soil. - In: Gupta, V. K. et al. (eds), Laboratory protocols in fungal biology, current methods in fungal biology. Springer, pp. 349-356.

Harrison, K. A. et al. 2008. Do plant species with different growth strategies vary in their ability to compete with soil microbes for chemical forms of nitrogen? - Soil Biol. Biochem. 40: 228-237.

Hättenschwiler, S. and Vitousek, P. M. 2000. The role of polyphenols in terrestrial ecosystem nutrient cycling. - Trends Ecol. Evol. 15: 238-243.

Hertel, D. and Scholing, D. 2011. Norway spruce shows contrasting changes in below- versus above-ground carbon partitioning towards the alpine tree line: evidence from a central European case study. - Arct. Antarct. Alpine Res. 43: 46-55.

Kaye, J. P. and Hart, S. C. 1997. Competition for nitrogen between plants and soil microorganisms. - Trends Ecol. Evol. 12: $139-143$.

Körner, C. 1998. A re-assessment of high elevation treeline positions and their explanation. - Oecologia 115: 445-459.

Körner, C. and Paulsen, J. 2004. A world-wide study of high altitude treeline temperatures. - J. Biogeogr. 31: 713-732.

Legay, N. et al. 2013. Comparison of inorganic nitrogen uptake dynamics following snowmelt and at peak biomass in subalpine grasslands. - Biogeosciences 10: 7631-7645.

Leonelli, G. et al. 2011. Climate warming and the recent treeline shift in the European Alps: the role of geomorphological factors in high-altitude sites. - Ambio 40: 264-273.

Loomis, P. F. et al. 2006. Nitrogen cycling at treeline: latitudinal and elevational patterns across a boreal landscape. - Ecoscience 13: 544-556.

McNown, R. W. and Sullivan, P. F. 2013. Low photosynthesis of treeline white spruce is associated with limited soil nitrogen availability in the Western Brooks Range, Alaska. - Funct. Ecol. 27: 672-683

Payette, S. 2007. Contrasted dynamics of northern Labrador tree lines caused by climate change and migrational lag. - Ecology 88: 770-780.

Perez, C. A. et al. 1998. Nitrogen mineralization in two unpolluted old-growth forests of contrasting biodiversity and dynamics. - Ecosystems 1: 361-373.

Reay, D. S. et al. 2008. Global nitrogen deposition and carbon sinks. - Nat. Geosci. 1: 430-437.

Robertson, G. P. et al. 1999. Standard soil methods for long-term ecological research. - Oxford Univ. Press.

Romanya, J. et al. 2005. Soil-plant relationships and tree distribution in old growth Nothofagus betuloides and Nothofagus pumilio forests of Tierra del Fuego. - Geoderma 124: 169-180.

Roy, J. et al. 2013. Microbes on the cliff: alpine cushion plants structure bacterial and fungal communities. - Front. Microbiol. 4: 64-64.

Saccone, P. et al. 2013. The effects of snowpack properties and plant strategies on litter decomposition during winter in subalpine meadows. - Plant Soil 363: 215-229.

Schmidt, I. K. et al. 1999. Mineralization and microbial immobilization of $\mathrm{N}$ and $\mathrm{P}$ in arctic soils in relation to season, temperature and nutrient amendment. - Appl. Soil Ecol. 11: $147-160$.

Shi, P. et al. 2008. A test of the growth-limitation theory for alpine tree line formation in evergreen and deciduous taxa of the eastern Himalayas. - Funct. Ecol. 22: 213-220.

Sundqvist, M. K. et al. 2011. Interactive effects of vegetation type and elevation on aboveground and belowground properties in a subarctic tundra. - Oikos 120: 128-142. 
Sundqvist, M. K. et al. 2012. Chemical properties of plant litter in response to elevation: subarctic vegetation challenges phenolic allocation theories. - Funct. Ecol. 26: 1090-1099.

Sundqvist, M. K. et al. 2013. Community and ecosystem responses to elevational gradients: processes, mechanisms and insights for global change. - Annu. Rev. Ecol. Evol. Syst. 44: 261-280.

Susiluoto, S. et al. 2010. Testing the growth limitation hypothesis for subarctic Scots pine. - J. Ecol. 98: 1186-1195.

van de Weg, M. J. et al. 2009. Altitudinal variation in leaf mass per unit area, leaf tissue density and foliar nitrogen and phosphorus content along an Amazon-Andes gradient in Peru. - Plant Ecol. Divers. 2: 243-254.

van der Heijden, M. G. A. et al. 2008. The unseen majority: soil microbes as drivers of plant diversity and productivity in terrestrial ecosystems. - Ecol. Lett. 11: 296-310.

Wardle, D. A. et al. 2004. Ecological linkages between aboveground and belowground biota. - Science 304: 1629-1633.

Supplementary material (available online as Appendix oik00860 at $<$ www.oikosoffice.lu.se/appendix $>$ ). Appendix 1.
Wardle, P. and Coleman, M. C. 1992. Evidence for rising upper limits of 4 native New Zealand forest trees. - N. Z. J. Bot. 30: 303-314.

White, T. J. et al. 1990. Amplification and direct sequencing of fungal ribosomal RNA genes for phylogenetics. - In: Innis, M. A. et al. (eds), PCR protocols: a guide to methods and applications. Academic Press, pp. 315-322.

Wookey, P. A. et al. 2009. Ecosystem feedbacks and cascade processes: understanding their role in the responses of arctic and alpine ecosystems to environmental change. - Global Change Biol. 15: 1153-1172.

Wu, Y. P. et al. 2009. Effects of different soil weights, storage times and extraction methods on soil phospholipid fatty acid analyses. - Geoderma 150: 171-178.

Zinger, L. et al. 2008. CE-SSCP and CE-FLA, simple and high-throughput alternatives for fungal diversity studies. - J. Microbiol. Meth. 72: 42-53.

Zinger, L. et al. 2011. Contrasting diversity patterns of crenarchaeal, bacterial and fungal soil communities in an alpine landscape. - Plos One 6: e19950. 